\title{
Consequences of elevated temperatures on legume biomass and nitrogen cycling in a field warming and biodiversity experiment in a North American prairie
}

\author{
Heather R. Whittington ${ }^{\mathrm{A}, \mathrm{C}}$, David Tilman ${ }^{\mathrm{B}}$ and Jennifer S. Powers ${ }^{\mathrm{A}, \mathrm{B}}$ \\ ADepartment of Plant Biology, University of Minnesota, 1445 Gortner Avenue, Saint Paul, MN 55108, USA. \\ ${ }^{B}$ Department of Ecology, Evolution, and Behavior, University of Minnesota, Saint Paul, MN 55108, USA. \\ ${ }^{\mathrm{C}}$ Corresponding author. Email: whitt092@umn.edu
}

\begin{abstract}
Increases in global temperature are likely to have effects on the nitrogen cycle, including those mediated through effects on legumes, which have a role in the $\mathrm{N}$ cycle by fixing $\mathrm{N}_{2}$. These effects may alter plant functioning and community structure, especially in N-limited ecosystems. We manipulated temperature and plant diversity in the field to investigate the effects of elevated temperature on aboveground biomass, shoot $\mathrm{N}$ concentration $([\mathrm{N}])$, and reliance on $\mathrm{N}_{2}$ fixation of four prairie legumes (Amorpha canescens Pursh., Dalea purpurea Vent., Lespedeza capitata Michx. and Lupinus perennis L.) planted in plots of varying species numbers. We monitored the effect of warming on soil microclimate and net $\mathrm{N}$ mineralisation rates, as these variables may mediate the effect of warming on legumes. Warming decreased soil moisture and increased soil temperature, but had no effect on net $\mathrm{N}$ mineralisation. Warming increased the aboveground biomass of D. purpurea and L. perennis, but decreased shoot $[\mathrm{N}]$ for all species in one year. Though the data were not optimal for quantifying $\mathrm{N}_{2}$ fixation using stable isotopes, they suggest that warming did not affect the reliance on $\mathrm{N}_{2}$ fixation. Species diversity did not have strong effects on the response to warming. These results suggest that legume-mediated effects of temperature on $\mathrm{N}$ cycling will arise from changes in biomass and tissue chemistry, not $\mathrm{N}_{2}$ fixation. We observed strong interannual variation between a wet and dry year for $\mathrm{N}$ mineralisation, shoot $[\mathrm{N}]$ and reliance on $\mathrm{N}_{2}$ fixation, suggesting that these may be more responsive to precipitation changes than elevated temperature.
\end{abstract}

Additional keywords: Amorpha canescens, Dalea purpurea, grassland, Lespedeza capitata, Lupinus perennis, Petalostemum purpureum.

Received 17 November 2012, accepted 17 May 2013, published online 28 June 2013

\section{Introduction}

Nitrogen is a limiting nutrient in many temperate ecosystems (LeBauer and Treseder 2008; Craine and Jackson 2010). Because many aspects of the $\mathrm{N}$ cycle are impacted by temperature and water availability, climate change has the potential to affect plant and ecosystem function by altering the $\mathrm{N}$ cycle (Shaver et al. 2000; Rustad et al. 2001). In addition, recent modelling studies indicate that including $\mathrm{N}$ dynamics and feedback in global simulation models can significantly alter predictions when compared with models that do not include coupling of the carbon and N cycles (Thornton et al. 2009; Zaehle et al. 2010). Understanding the effects of climate change on the $\mathrm{N}$ cycle is crucial to predicting the future response of ecosystems as well as vegetation feedback, such as soil carbon sequestration, to climate (Hungate et al. 2003; Finzi et al. 2011).

Legumes play an influential role in $\mathrm{N}$ cycling because their $\mathrm{N}_{2}$ fixation and high-N litter is a major source of new $\mathrm{N}$ inputs (Vitousek and Walker 1989; Craine et al. 2002). In prairies in the United States of America (USA), $\mathrm{N}_{2}$-fixing legumes comprise $1-17 \%$ of biomass (Piper et al. 2007) and have been estimated to account for $\sim 5 \%$ of the total (new plus recycled) $\mathrm{N}$ inputs from litter (Woodmansee et al. 1981), with the exact contribution likely to be mediated by their abundance. However, even small changes in new $\mathrm{N}$ input rates may have a large impact in these N-limited communities over time (Kindscher and Tieszen 1998). Thus, knowledge of legume functioning under future climate conditions is an important component to understanding how $\mathrm{N}$ and $\mathrm{C}$ cycling may change. Most studies focus on crop or forage legumes, and few examine legumes growing in multispecies mixtures. In an old field experiment in Tennessee, warming decreased the aboveground biomass of a forage legume but increased the biomass of a legume shrub (Garten et al. 2008). The same study also found a significant effect of warming on $\mathrm{N}_{2}$ fixation by these two legumes (Garten et al. 2008). Comparatively little research has examined the effects of climate change on legumes in prairie grasslands in the USA.

Elevated temperature can influence $\mathrm{N}_{2}$ fixation through several direct and indirect pathways. Soil temperature affects many aspects of the $\mathrm{N}_{2}$ fixation process, including nodulation (Barrios et al. 1963; Purwantari et al. 1995), nodule development (Piha and Munns 1987) and nodule activity (Meyer and Anderson 1959; Hungria and Franco 1993). Both extreme soil temperatures 
and drought inhibit all of these aspects (Serraj et al. 1999; Aranjuelo et al. 2007). Legumes typically have lower rates of $\mathrm{N}_{2}$ fixation in higher soil mineral $\mathrm{N}$ (Allos and Bartholomew 1955; West et al. 2005). Net $\mathrm{N}$ mineralisation is often used as an index of plant available N (Schimel and Bennett 2004). In a meta-analysis, Rustad et al. (2001) found that elevated temperature increased net $\mathrm{N}$ mineralisation in several studies but warming had no effect in others. Moreover, the response of mineralisation to temperature may vary within a growing season (Shaw and Harte 2001) or between years (Wan et al. 2005), and is likely to be mediated by soil moisture (Verburg et al. 2009). Furthermore, temperature may affect $\mathrm{N}_{2}$-fixation through its effect on photosynthesis and respiration. Warming increased photosynthesis and respiration in the spring and decreased photosynthesis in the autumn for several species during a field warming study in Oklahoma (Zhou et al. 2007). For both Trifolium repens L. (white clover) and Medicago sativa $\mathrm{L}$. (lucerne), $\mathrm{N}_{2}$ fixation increased when air temperature increased but root temperature remained constant (Harding and Sheehy 1980; Kessler et al. 1990). By altering photosynthesis and respiration, temperature can alter the demand for $\mathrm{N}$ and the amount of carbon substrate available for $\mathrm{N}_{2}$ fixation.

Temperature effects on $\mathrm{N}$ cycling and legumes may also be influenced by plant diversity and the context of the surrounding plant community. Diversity, often measured as species richness, affects both abiotic soil conditions such as temperature and moisture, and biotic processes such as $\mathrm{N}$ dynamics by affecting supply and demand (Hooper et al. 2005). Both negative and positive correlations between soil moisture and species number have been reported, and the relationship may depend on season, soil type or the interaction between plants and the soil (De Boeck et al. 2006; Fornara and Tilman 2009). Increases in temperature are expected to decrease soil moisture by increasing evapotranspiration (Harte et al. 1995; De Boeck et al. 2006). In grasslands, greater shading at higher diversity may attenuate this effect, but greater biomass at higher diversity could also lead to higher water demand and evapotranspiration. No interaction between warming and diversity was seen in a warming study in mesocosms that varied in species number (De Boeck et al. 2006). Mineral soil $\mathrm{N}$ availability (as indicated by potential mineralisation rates) may be higher in more diverse plant communities (Zak et al. 2003; Oelmann et al. 2011). However, demand and competition for mineral $\mathrm{N}$ is likely to be greater at higher diversity, causing legumes to increase their reliance on $\mathrm{N}_{2}$ fixation as species numbers increase (Carlsson et al. 2009; Roscher et al. 2011).

To better understand the possible consequences of climate change on legume functioning and their impact on $\mathrm{N}$ cycling in prairies, we used a manipulative field warming experiment to examine the response of four native legumes (Amorpha canescens Pursh, Dalea purpurea Vent., Lespedeza capitata Michx. and Lupinus perennis L.) to elevated temperature in a biodiversity experiment in central Minnesota, USA. These species are widely distributed, vary in traits such as phenology and nodule type (Sprent 2001), and showed contrasting responses to a $3^{\circ} \mathrm{C}$ temperature gradient under controlled conditions in a growth chamber experiment (Whittington et al. 2012). In that experiment, L. capitata seedlings displayed higher biomass when grown at $28^{\circ} \mathrm{C}$ compared with $25^{\circ} \mathrm{C}$, whereas $L$. perennis seedlings showed decreased shoot $\mathrm{N}$ concentration $([\mathrm{N}])$ and nodulation at the higher temperature. These greenhouse results suggest that these species have the potential to respond differently to warming, but mature plants in the field may not show the same responses as seedlings growing in the greenhouse. Here, we examine (1) the effect of warming on $\mathrm{N}_{2}$ fixation and three of its potential drivers (soil temperature, soil moisture and mineral $\mathrm{N}$ availability), (2) the effect of warming on legume biomass and tissue $\mathrm{N}$ chemistry, and (3) how diversity and interannual variability affect the response of these variables to experimental warming.

\section{Materials and methods}

\section{Experimental setup}

We examined the effects of elevated temperature on legumes in a large field warming experiment that was established in a longterm ( $>15$ years) biodiversity experiment at Cedar Creek Ecosystem Science Reserve (East Bethel, MN) (Tilman et al. 2001). This site occurs on a glacial outwash sandplain with sandy soils low in $\mathrm{N}$. The mean annual temperature is $6.8^{\circ} \mathrm{C}$ (Cedar Creek Ecosystem Science Reserve 2009). Mean growing season (April to September) temperature is $16.3^{\circ} \mathrm{C}$ and the mean winter (December to March) temperature is $-6.3^{\circ} \mathrm{C}$. The mean annual precipitation is $799 \mathrm{~mm}$, with $72 \%$ typically falling during the growing season. In 2009, the mean growing season temperature was $16.1^{\circ} \mathrm{C}$, with a minimum of $-18^{\circ} \mathrm{C}$ and a maximum of $36^{\circ} \mathrm{C}$. It was slightly warmer in 2010 , with a mean growing season temperature of $17.2^{\circ} \mathrm{C}, \mathrm{a}-5^{\circ} \mathrm{C}$ minimum and a $36^{\circ} \mathrm{C}$ maximum. The mean winter temperatures were $-8.6^{\circ} \mathrm{C}$ and $-5.2^{\circ} \mathrm{C}$ before the 2009 and 2010 growing seasons, respectively. Cumulative precipitation during the growing season was $388 \mathrm{~mm}$ in 2009; 2010 was considerably wetter, with $655 \mathrm{~mm}$ rainfall.

In 1994 and 1995, $9 \mathrm{~m} \times 9 \mathrm{~m}$ plots were seeded with 1, 2, 4, 8, 16 or 32 species of grassland plants native or naturalised to Minnesota (Tilman et al. 2001). In 2008, 38 of these plots were selected to be part of the Biodiversity and Climate warming experiment. These plots consist of six 32-species plots, nine 16-species plots, nine 4-species plots and one monoculture plot of each of the following species: Achillea millifolium L., Amorpha canescens Pursh., Andropogon gerardii Vitman, Dalea purpurea Vent. (Petalostemum purpureum Vent.), Koeleria cristata Pers., Lespedeza capitata Michx., Liatris aspera Michx., Lupinus perennis L., Panicum virgatum, Poa pratensis L., Schizachyrium scoparium (Michx.) Nash, Solidago rigida L. and Sorghastrum nutans (L.) Nash. Each plot was split into three $2.5 \mathrm{~m} \times 3 \mathrm{~m}$ subplots with different warming treatments: ambient, low and high. Warming was achieved via infrared heat lamps (Kalglo Electronics, Bethlehem, PA, USA) suspended $1.8 \mathrm{~m}$ above the ground from metal frames. Lamps over high and low subplots emitted $1200 \mathrm{~W}$ and $600 \mathrm{~W}$, respectively. These lamp parameters were chosen to increase the surface soil temperature in bare ground plots by $3^{\circ} \mathrm{C}$ and $1.5^{\circ} \mathrm{C}$ for the high and low warming treatments respectively. Extensive testing of the warming footprint was done before installing the lamps to verify that these targeted soil temperatures were achieved. Metal flanges over the lamp and a metal bar under the lamp helped distribute heat over the 
subplot. Metal flanges and frames (without lamps) were also hung over ambient subplots to account for any possible effect of shading. Heating occurred during March to November. Here, we report data collected during 2009 and 2010.

\section{Soil temperature and moisture}

Surface soil temperature in each subplot was monitored hourly with three iButtons (Maxim, Sunnyvale, CA, USA), installed $2 \mathrm{~cm}$ below the surface. For each subplot, the mean soil temperature recorded during the in situ $\mathrm{N}$ mineralisation incubation periods was analysed. Soil moisture in the top $18 \mathrm{~cm}$ was measured gravimetrically as part of the $\mathrm{N}$ mineralisation measurements. One initial soil core (see below) was taken from each subplot in May, July and September of 2009 and 2010. A 10-g sample of soil from each core was weighed, dried at $105^{\circ} \mathrm{C}$ for $48 \mathrm{~h}$ and reweighed.

\section{Biomass}

Aboveground biomass of legumes in each subplot was estimated by harvesting plants in early August in 2009 and 2010, and is used as a proxy for abundance. In each subplot, all biomass $1 \mathrm{~cm}$ above the ground was clipped from two $10 \mathrm{~cm} \times 1.5 \mathrm{~m}$ strips. The location of these strips was the same for all subplots but varied between years to avoid resampling the same location. Tissue was sorted into species, dried and weighed.

\section{Stable nitrogen isotope analysis and $N_{d f a}$ calculations}

The stable isotopic content of nitrogen, $\delta^{15} \mathrm{~N}$, was measured on harvested legume tissue to estimate $\mathrm{N}_{2}$ fixation through the ${ }^{15} \mathrm{~N}$ natural abundance method. This method relies on a difference in the stable isotopic composition of mineral soil $\mathrm{N}$ compared with that of air. Legumes relying more on $\mathrm{N}_{2}$ fixation will have $\delta^{15} \mathrm{~N}$ values closer to zero, which is the $\delta^{15} \mathrm{~N}$ level of air. Shoot tissue samples (i.e. stems plus leaves) from two individuals in each subplot of the polyculture plots and from three individuals in each monoculture subplot were dried $\left(65^{\circ} \mathrm{C}\right)$, finely ground and analysed for $\mathrm{N}$ concentration and its stable isotopes at the Stable Isotope Facility at University of California, Davis, on a PDZ Europa ANCA-GSL elemental analyser coupled to a PDZ Europa 20-20 isotope ratio mass spectrometer (Sercon Ltd, Cheshire, UK). Shoot tissue of nonlegume individuals from subplots that did not contain legumes was also analysed to act as reference plants (i.e. the $\delta^{15} \mathrm{~N}$ signatures of these plants represent the values of plants grown using $\mathrm{N}$ sources from the soil only). Reference species were restricted to the $\mathrm{C}_{3}$ forbs planted in the experiment: A. millifolium, M. fistulata and S. rigida.

The percent of nitrogen derived from fixation $\left(\% \mathrm{~N}_{\mathrm{dfa}}\right)$ was estimated with Eqn 1 (Shearer and Kohl 1989):

$$
\% N_{\text {dfa }}=\frac{\delta^{15} N_{\text {reference_plant }}-\delta^{15} N_{\text {legume }}}{\delta^{15} N_{\text {reference_plant }}-\delta^{15} N_{\text {fixed }}} \times 100 \text {. }
$$

In theory, the reference plants approximate the $\delta^{15} \mathrm{~N}$ value of available mineral nitrogen in the soil. Ideally, the reference plant(s) chosen should be similar to the legume of interest, especially in rooting depth, phenology and mycorrhizal status, as these characteristics influence where and when mineral $\mathrm{N}$ is obtained. Good matches, however, can be difficult to find, especially when restricted to planted communities like our field experiment. For this reason, we used mean values from the three species above as our reference. Some legume individuals displayed $\delta^{15} \mathrm{~N}$ values above the mean reference value, yielding negative $\% \mathrm{~N}_{\mathrm{dfa}}$ values. We set these values of estimated $\% \mathrm{~N}_{\text {dfa }}$ to zero. The $\delta^{15} \mathrm{~N}$ of fixed $\mathrm{N}$ (referred to as the $B$-value) is defined as the species-specific isotopic composition of tissue when legume plants are grown using $\mathrm{N}_{2}$ fixation as the sole $\mathrm{N}$ source, and is typically determined in growth chamber experiments. We found that our field values of legume $\delta^{15} \mathrm{~N}$ were lower than the $B$-values that we measured previously in a growth chamber experiment (Whittington et al. 2012), most probably because the rhizobial strains used in the laboratory experiment did not fully match those in the field. Because of this, we used the lowest $\delta^{15} \mathrm{~N}$ value from the field as the $B$-value, making the assumption that at least one individual is fixing $100 \%$ of its $\mathrm{N}$.

Shoot carbon concentration $([\mathrm{C}])$ and $[\mathrm{N}]$ values were measured at the same time as nitrogen isotopic composition. Total shoot $\mathrm{N}$ content was calculated by multiplying mean shoot $[\mathrm{N}]$ for each species in each subplot by the harvested biomass for that species in that subplot.

\section{Net $N$ mineralisation}

Net $\mathrm{N}$ mineralisation was measured three times a year (late spring, summer and autumn) using 1-month in situ incubations as an index of plant-available mineral N. Very similar methods have been used in other experiments at this site (Wedin and Tilman 1990; Dijkstra et al. 2006). At the start of each interval in midMay, mid-July or mid-September, two tubes $18 \mathrm{~cm}$ in length and $2 \mathrm{~cm}$ in diameter were hammered into each subplot. One tube was removed immediately and the soil stored in plastic freezer bags on ice until $\mathrm{N}$ extraction within $24 \mathrm{~h}$. The second tube was capped and left in the ground for 1 month before it was removed and

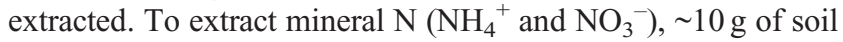
was added to $50 \mathrm{~mL}$ of $2 \mathrm{M} \mathrm{KCl}$, shaken for $1 \mathrm{~h}$ and then filtered through Whatman1 filter paper (GE Healthcare, UK). Blanks were created by shaking and filtering $\mathrm{KCl}$ without added soil. The extracts were stored at $-20^{\circ} \mathrm{C}$ until further analysis. Soil moisture was measured gravimetrically at the time of extraction as described above.

The amount of $\mathrm{NH}_{4}{ }^{+}$and $\mathrm{NO}_{3}{ }^{-}$in the $\mathrm{KCl}$ soil extracts was measured colourimetrically using a protocol based on Weatherburn (1967) or Doane and Horwath (2003), respectively, modified for 96-well plates (Allison and Treseder 2008). Absorbance was measured with a SpectraMax Plus spectrophotometer (Molecular Devices, Sunnyvale, CA, USA) equipped with a plate reader. Dilutions of $\mathrm{NH}_{4} \mathrm{Cl}$ and $\mathrm{KNO}_{3}$ solutions were used to create standard curves for each plate. Each plate contained three replicates of each sample and standard, which were averaged. We calculated net $\mathrm{N}$ mineralisation rates as the difference in blank-corrected $\mathrm{NH}_{4}{ }^{+}$and $\mathrm{NO}_{3}{ }^{-}$between the final and initial cores, divided by the number of days of field incubation and expressed on a dry soil weight basis. Net ammonification and nitrification rates were similarly calculated for $\mathrm{NH}_{4}{ }^{+}$or $\mathrm{NO}_{3}^{-}$only. 


\section{Statistical analysis}

We used repeated-measures ANOVA to examine the effects of year, warming, diversity and incubation period (late spring, summer and autumn) on net $\mathrm{N}$ mineralisation, ammonification, nitrification and initial soil moisture (measured on soil extracted with the initial $\mathrm{N}$ mineralisation core). Unfortunately, we have no measurements of soil temperature during the late spring 2009 incubation period, so we ran separate repeated-measures ANOVAs for each year to determine the effect of warming treatment, diversity and incubation period on the mean surface soil temperature. The 32-species plots were originally seeded using a different species mix containing some species that are not present in the lower diversity treatments and thus cannot be included in analyses that include diversity as a factor. For this reason, 32-species plots were analysed separately with ANOVAs similar to those above but without the diversity effect.

We used ANOVA to determine the effect of warming treatment, species, year and diversity on variables measured on focal legume individuals (biomass, $\% \mathrm{~N}_{\mathrm{dfa}}$, shoot $[\mathrm{N}]$, shoot $\mathrm{C}: \mathrm{N}$ ratio and total shoot $\mathrm{N}$ content). However, the following experimental constraints prevented us from examining all main effects and interactions in a single ANOVA model: (i) monoculture plots were not replicated for individual species; (ii) by design, not all legume species occur in the 4species plots; and (iii) the 32-species plots were planted using a different seed mix and thus are not included in any of the diversity analyses. For these reasons, we analysed subsets of the data separately to highlight various aspects of the warming effect. In the first model, we limited our analysis to the two species (D. purpurea and L. capitata) that were found in both 4-and 16-species plots in order to examine potential species $\times$ diversity interactions. The second model included species as a random factor to examine the effect of diversity at three levels (1-, 4-and 16-species plots). The third model focussed on differences among species and only used data from high diversity plots (16- and 32-species plots) where all legume species were present.
Repeated-measures ANOVAs were performed with SAS ver. 9.2 software (SAS Institute, Cary, NC, USA). All other analyses were performed with JMP Pro ver. 9.0 software (SAS Institute). In each of the analyses, plot and its interaction with subplot were included as random factors to account for the split-plot design, where diversity was the whole-plot factor and the warming treatment was the split-plot factor. Aboveground biomass and $\% \mathrm{~N}_{\text {dfa }}$ were square root-transformed and total shoot $\mathrm{N}$ was logtransformed to improve the normality of residuals.

\section{Results}

Warming effects

Experimental warming significantly increased surface soil temperature by $0.5-2.5^{\circ} \mathrm{C}$ during all incubation periods except for the 16-species plots in the late spring of 2010 and for the 32 -species plots in the summer of 2010 (Tables 1, 2). Generally, soil temperatures under high warming were significantly greater than those under low warming. High warming significantly decreased soil moisture (measured on initial samples during $\mathrm{N}$ mineralisation incubations) by $9 \%$ compared with ambient temperatures, although this was largely driven by the $20 \%$ decrease under warming in the summer of 2009 (Fig. 1). Low warming did not significantly affect soil moisture compared with ambient temperatures.

Mean net $\mathrm{N}$ mineralisation rates were low but consistently positive except for the autumn of 2009. Net $\mathrm{N}$ mineralisation was unaffected by either warming treatment (Fig. 2a,b). Results were similar when expressing mineralisation per $\mathrm{g}$ of soil or per $\mathrm{g}$ of soil $\mathrm{N}$. When $\mathrm{NH}_{4}{ }^{+}$and $\mathrm{NO}_{3}{ }^{-}$dynamics were examined separately, warming only affected net ammonification in 2010 during autumn when high and low warming increased net ammonification by $50 \%$ and $13 \%$, respectively, compared with ambient temperatures (Fig. $2 c, d$ ). Neither warming treatment had any effect on net nitrification (Table 1). The ratio of ammonification to nitrification was 1.1 in 2009 and 0.067 in 2010 .

Table 1. F-ratios (degrees of freedom) times a year during the first 2 years of a warming and plant diversity experiment

$\mathrm{Y}$, year; $\mathrm{D}$, diversity; $\mathrm{W}$, warming; $\mathrm{P}$, incubation period; $\dagger$, significant effect at $P<0.1$; ${ }^{*}$ significant effect at 0.05 . The first degrees of freedom (d.f.) value is the numerator d.f. and the second value is the denominator d.f.

\begin{tabular}{|c|c|c|c|c|c|c|}
\hline \multirow[t]{2}{*}{ Effect $^{\mathrm{A}}$} & \multicolumn{2}{|c|}{ Soil temperature $^{\mathrm{B}}$} & \multirow{2}{*}{$\begin{array}{c}\text { Soil } \\
\text { moisture }\end{array}$} & \multirow{2}{*}{$\begin{array}{c}\text { Net } \mathrm{N} \\
\text { mineralisation }\end{array}$} & \multirow{2}{*}{$\begin{array}{c}\text { Net } \\
\text { ammonification }\end{array}$} & \multirow{2}{*}{$\begin{array}{c}\text { Net } \\
\text { nitrification }\end{array}$} \\
\hline & 2009 & 2010 & & & & \\
\hline Y & - & - & $4177_{(1,167)} *$ & $5.5_{(1,104)} *$ & $0.2_{(4,128)}$ & $12 \cdot 4_{(1,126)}$ * \\
\hline D & $16.4_{(2,28)} *$ & $26.2_{(2,29)} *$ & $2 \cdot 1_{(2,29)}$ & $0.4_{(2,45)}$ & $0.5_{(2,23)}$ & $0.9_{(2,23)}$ \\
\hline W & $334.8_{(2,17)}$ * & $314.3_{(2,58)} *$ & $17 \cdot 5_{(2,58)} *$ & $1.0_{(2,45)}$ & $3 \cdot 1_{(2,55)}^{\dagger}$ & $0.2_{(2,53)}$ \\
\hline$P$ & $8756.9_{(1,87)} *$ & $7843_{(2,126)}$ * & $247.5_{(2,336)}$ * & $1.9_{(2,168)}$ & $2 \cdot 1_{(2,174)}$ & $8 \cdot 0_{(2,172)} *$ \\
\hline $\mathrm{Y} \times \mathrm{D}$ & - & - & $25.2_{(2,167)}$ * & $0.5_{(2,104)}$ & $0.5_{(2,128)}$ & $1.3_{(2,126)}$ \\
\hline $\mathrm{Y} \times \mathrm{W}$ & - & - & $0.8_{(2,158)}$ & $1.0_{(2,105)}$ & $4 \cdot 0_{(2,128)}$ * & $0.1_{(2,126)}$ \\
\hline $\mathrm{Y} \times \mathrm{P}$ & - & - & $74 \cdot 8_{(2,314)} *$ & $3.4_{(2,185)}$ * & $2.5_{(2,185)}^{\dagger}$ & $10.0_{(2,188)} *$ \\
\hline $\mathrm{D} \times \mathrm{W}$ & $7.7_{(4,17)}$ * & $14.4_{(4,58)} *$ & $0.3_{(4,58)}$ & $0.5_{(4,46)}$ & $1.0_{(4,56)}$ & $0.6_{(4,54)}$ \\
\hline $\mathrm{D} \times \mathrm{P}$ & $22 \cdot 6_{(2,87)} *$ & $23 \cdot 3_{(4,137)}$ * & $2.8_{(4,340)} *$ & $0.3_{(4,170)}$ & $0.7_{(4,177)}$ & $1.0_{(4,174)}$ \\
\hline $\mathrm{W} \times \mathrm{P}$ & $0.4_{(2,87)}$ & $12.0_{(4,137)} *$ & $2 \cdot 8_{(4,340)} *$ & $1.2_{(4,170)}$ & $3.4_{(4,177)} *$ & $0.2_{(4,174)}$ \\
\hline $\mathrm{Y} \times \mathrm{W} \times \mathrm{P}$ & - & - & $2 \cdot 1_{(4,344) \dagger} \dagger$ & $1.1_{(4,215)}$ & $2.5_{(4,216)}$ * & $0.3_{(4,218)}$ \\
\hline $\mathrm{D} \times \mathrm{W} \times \mathrm{P}$ & $0.5_{(4,87)}$ & $2.4_{(8,147)}$ * & $1.4_{(8,341)}$ & $0.8_{(8,169)}$ & $1.1_{(8,177)}$ & $0.8_{(8,174)}$ \\
\hline
\end{tabular}

\footnotetext{
${ }^{\mathrm{A}}$ Insignificant $(P>0.1)$ three-way and four-way interactions are not shown.

${ }^{\mathrm{B}}$ Soil temperature data were analysed by year because we have no late spring measurements in 2009 .
} 
Table 2. Mean increase $\left( \pm\right.$ s.e.) in surface soil temperature $\left({ }^{\circ} \mathrm{C}\right)$ from ambient in plots varying in plant species diversity under two levels of warming

Bold values indicate a significant $(P<0.05)$ difference from the ambient treatment

\begin{tabular}{lcccccc}
\hline Year & Warming & Incubation & \multicolumn{4}{c}{ Diversity level } \\
& treatment & period & 1 species & 4 species & 16 species & 32 species \\
\hline 2009 & \multirow{2}{*}{ High } & Summer & $\mathbf{2 . 5} \pm \mathbf{0 . 1}$ & $\mathbf{2 . 3} \pm \mathbf{0 . 2}$ & $\mathbf{1 . 2} \pm \mathbf{0 . 2}$ & $\mathbf{2 . 0} \pm \mathbf{0 . 4}$ \\
& & Autumn & $\mathbf{2 . 5} \pm \mathbf{0 . 1}$ & $\mathbf{2 . 4} \pm \mathbf{0 . 2}$ & $\mathbf{1 . 7} \pm \mathbf{0 . 2}$ & $\mathbf{2 . 5} \pm \mathbf{0 . 2}$ \\
& \multirow{2}{*}{ Low } & Summer & $\mathbf{1 . 0} \pm \mathbf{0 . 1}$ & $\mathbf{1 . 1} \pm \mathbf{0 . 2}$ & $\mathbf{0 . 4} \pm \mathbf{0 . 2}$ & $\mathbf{0 . 9} \pm \mathbf{0 . 4}$ \\
& & Autumn & $\mathbf{1 . 2} \pm \mathbf{0 . 1}$ & $\mathbf{1 . 0} \pm \mathbf{0 . 2}$ & $\mathbf{0 . 8} \pm \mathbf{0 . 2}$ & $\mathbf{1 . 2} \pm \mathbf{0 . 1}$ \\
\hline \multirow{2}{*}{ High } & Late spring & $\mathbf{2 . 6} \pm \mathbf{0 . 2}$ & $\mathbf{1 . 7} \pm \mathbf{0 . 3}$ & $0.2 \pm 0.3$ & $\mathbf{1 . 7} \pm \mathbf{0 . 5}$ \\
& & Summer & $\mathbf{2 . 1} \pm \mathbf{0 . 1}$ & $\mathbf{1 . 7} \pm \mathbf{0 . 2}$ & $\mathbf{1 . 0} \pm \mathbf{0 . 3}$ & $0.8 \pm 0.2$ \\
& & Autumn & $\mathbf{3 . 1} \pm \mathbf{0 . 1}$ & $\mathbf{2 . 6} \pm \mathbf{0 . 4}$ & $\mathbf{2 . 6} \pm \mathbf{0 . 2}$ & $\mathbf{2 . 6} \pm \mathbf{0 . 5}$ \\
& \multirow{2}{*}{ Low } & Late spring & $\mathbf{1 . 0} \pm \mathbf{0 . 2}$ & $\mathbf{1 . 0} \pm \mathbf{0 . 1}$ & $-0.1 \pm 0.2$ & $\mathbf{0 . 8} \pm \mathbf{0 . 4}$ \\
& & Summer & $\mathbf{1 . 0} \pm \mathbf{0 . 1}$ & $\mathbf{0 . 8} \pm \mathbf{0 . 1}$ & $\mathbf{0 . 4} \pm \mathbf{0 . 1}$ & $0.8 \pm 0.1$ \\
& & Autumn & $\mathbf{1 . 3} \pm \mathbf{0 . 1}$ & $\mathbf{1 . 6} \pm \mathbf{0 . 3}$ & $\mathbf{1 . 2} \pm \mathbf{0 . 1}$ & $\mathbf{1 . 3} \pm \mathbf{0 . 3}$ \\
\hline
\end{tabular}

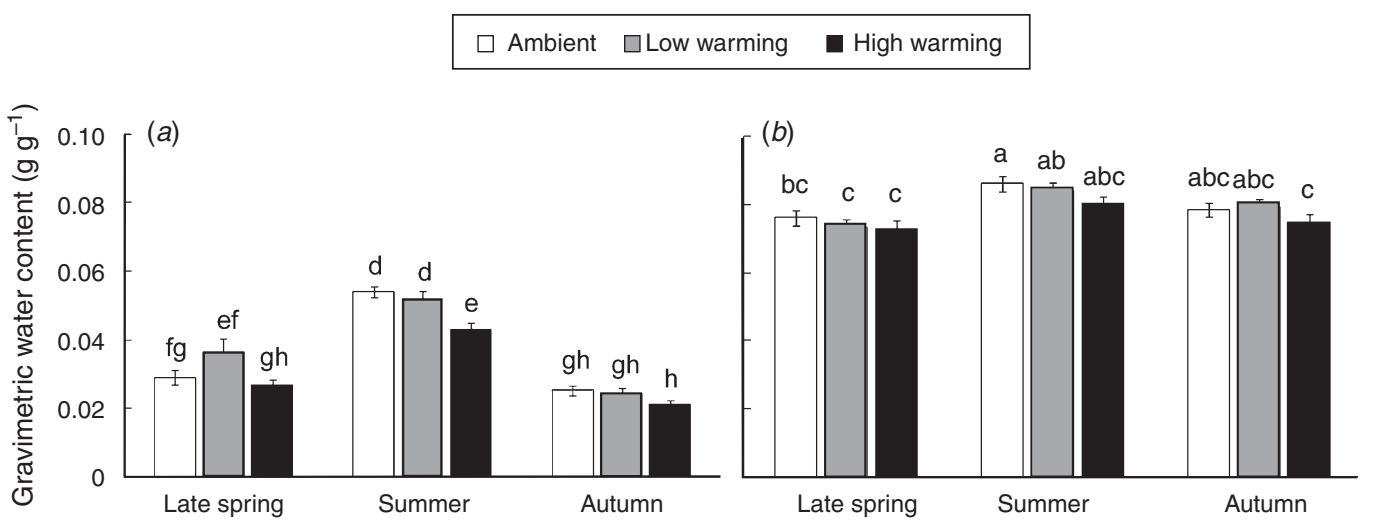

Fig. 1. The effect of warming on initial soil moisture measured at the start of three $\mathrm{N}$ mineralisation incubation periods in (a) 2009 and (b) 2010. Letters indicate significant differences among means $(P<0.05$, post hoc Tukey's honestly significant difference (HSD) test after ANOVA) across both years. Error bars indicate \pm s.e.

Legume shoot $\delta^{15} \mathrm{~N}$ values varied from $-4.43 \%$ o to $2.41 \%$ o (mean: $-2.06 \%$ ) and reference plant values overlapped legume values with a range of $-6.69 \%$ o to $3.40 \%$ (mean $-1.41 \%$ ), which presents a challenge for the natural abundance method for estimating $\% \mathrm{~N}_{\mathrm{dfa}}$ (see Discussion). Using these data, we found no evidence that either warming treatment affected $\% \mathrm{~N}_{\mathrm{dfa}}$ (Table 3). The significant species $\times$ warming interaction seen in Model 1 occurred because D. purpurea and L. capitata differed from each other in only two of the warming treatments. Within each species, there was no effect of warming.

In general, the three subsets of data yielded similar results for aboveground biomass (Table 3). High warming significantly affected the biomass of $D$. purpurea and L. perennis, but this effect depended upon year for D. purpurea. In 2010, D. purpurea aboveground biomass in the high warming treatment was over twice and four times that seen in the ambient treatment for the 4-species and 16-species plots, respectively (Fig. $3 a$ ). In the 16and 32 -species plots, L. perennis had $88 \%$ and $78 \%$ higher biomass under high and low warming, respectively, compared with ambient temperatures (Fig. 3c). The biomass of D. purpurea and $L$. perennis in the low warming treatment was not significantly different from either the high warming or ambient treatments.
Warming treatment affected shoot [N] only in 2010, when low and high warming decreased $[\mathrm{N}]$ by $8-32 \%$, depending on species (Table 4). Shoot C : N results were similar to shoot [N] (data not shown). Warming did not affect total shoot $\mathrm{N}$ content expressed on a ground area basis.

\section{Diversity effects}

In 2009, soil temperature was higher in the 1- and 4-species plots compared with 16-species plots during the summer, with no effect of diversity in the autumn. In 2010, 1- and 4-species plots displayed higher soil temperature than the 16-species plots during late spring and summer. In autumn 2010, soil temperature was higher in the monocultures compared with the 16-species plots.

Diversity did not affect net $\mathrm{N}$ mineralisation, ammonification or nitrification, but did affect $\mathrm{N}_{2}$ fixation (Tables 1,3). Plots with higher diversity generally displayed higher $\% \mathrm{~N}_{\mathrm{dfa}}$ values. In $2010, \% \mathrm{~N}_{\mathrm{dfa}}$ in the $16-$ and 4 -species plots was twice that in monocultures, whereas $\% \mathrm{~N}_{\mathrm{dfa}}$ was three times higher in the 16species plots compared with the 4-species plots in 2009 (Fig. 4b).

Legume biomass was $72 \%$ and $53 \%$ lower in the 16 -species plots than in the 1- or 4-species plots, respectively (Fig. 3b). 

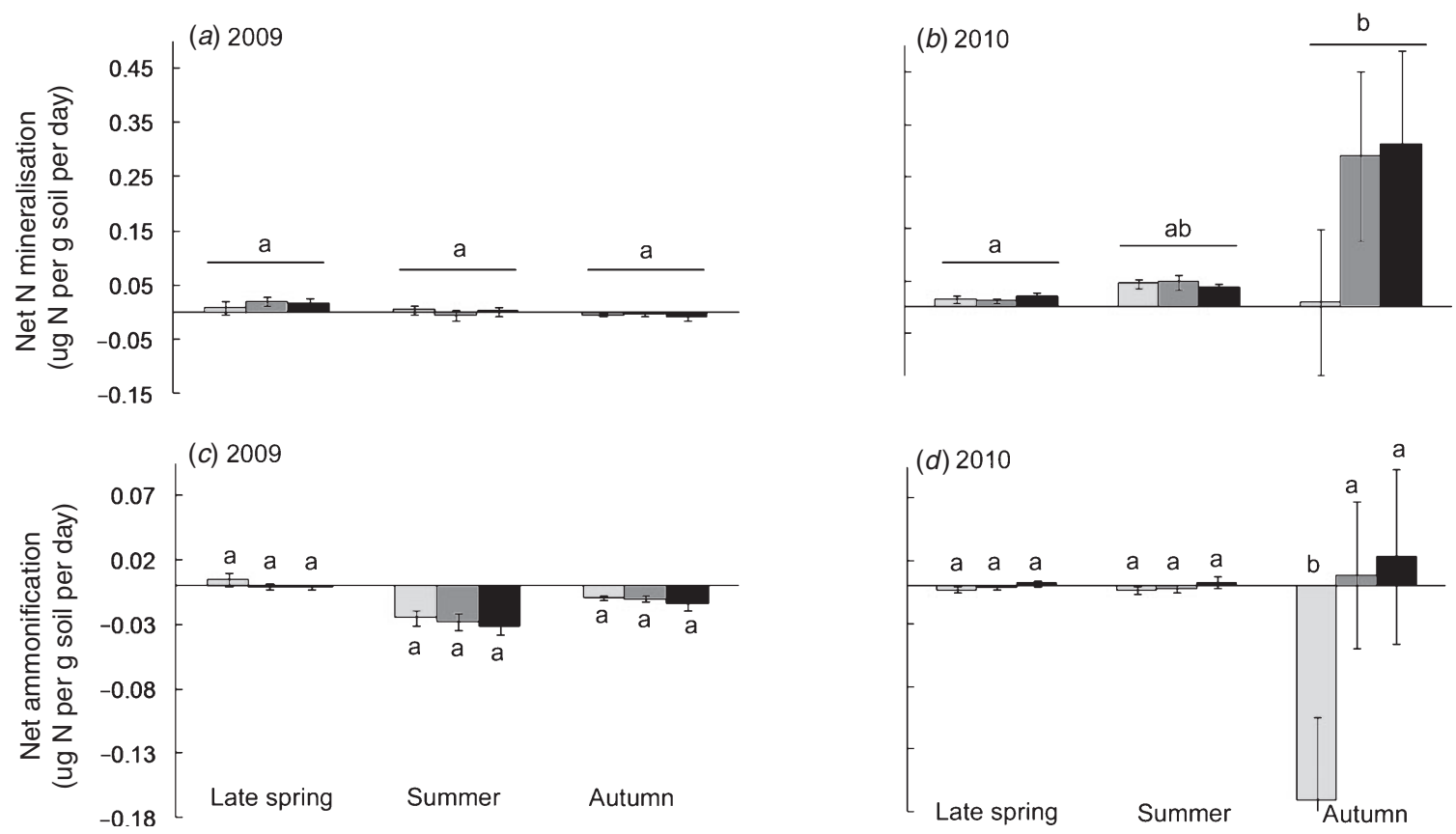

Fig. 2. The effect of warming treatment on $(a, b)$ net $\mathrm{N}$ mineralisation and $(c, d)$ net ammonification at three time periods in $(a, c)$ 2009 and $(b, d)$ 2010. Error bars indicate \pm s.e. Letters indicate significant differences across years $(P<0.05$, post hoc Tukey's honestly significant difference (HSD) tests after ANOVA).

Individuals of all species growing in monoculture displayed $6 \%$ and $22 \%$ higher shoot [N] than those in the four- and 16-species plots, respectively (Table 4). Following the trends seen for aboveground biomass, total shoot $\mathrm{N}$ content per ground area was lower in the 16-species plots compared with in the 1- and 4species plots.

\section{Warming and diversity interactions}

The effect of warming on soil temperature was influenced by diversity, with larger deviations from ambient conditions at low diversity (Table 2). Diversity did not affect the response of soil moisture or net $\mathrm{N}$ mineralisation to the warming treatment.

When species were pooled (Model 2), an effect of high warming on biomass was only detectable in the 16-species plots, where legume biomass was $81 \%$ greater under high warming than under ambient conditions (Fig. 3b). Additionally, the 2010 increase in D. purpurea biomass under warming in the 16-species plots was twice that seen in the 4species plots. Diversity did not affect the warming responses of shoot [N] or total shoot $\mathrm{N}$ content.

\section{Year and seasonal effects}

Soil moisture varied among years and seasons (Fig. 1). It was $126 \%$ higher in 2010 compared with 2009. In 2009, soil moisture was $31 \%$ and $111 \%$ higher in late spring and summer, respectively, compared with autumn. In 2010, soil moisture was $10 \%$ higher in summer than in late spring or autumn (Fig. 1).

Mineralisation during autumn was 30 times higher in 2010 than in 2009. In 2010, autumn mineralisation was eight times higher than late spring mineralisation in 2010. Interannual and seasonal variation in nitrification followed the trends seen for net mineralisation. Ammonification was not greatly affected by year or incubation period.

Significant interannual variation in $\% \mathrm{~N}_{\mathrm{dfa}}$ was evident in all three ANOVA models, mostly driven by interannual variation in D. purpurea and L. perennis (Fig. $4 b$ ). In D. purpurea, $\% \mathrm{~N}_{\mathrm{dfa}}$ was twice as high in 2010 than in 2009 , and L. perennis displayed $44 \%$ higher $\% \mathrm{~N}_{\mathrm{dfa}}$ values in 2010 than in 2009.

Aboveground biomass and tissue $\mathrm{N}$ chemistry variables also displayed significant differences between the years. In the 16- and 32-species plots (Model 3), A. canescens and L. perennis exhibited $60-63 \%$ less biomass in 2010 than 2009. Year accounted for the most variation in shoot [N], with $13-47 \%$ higher shoot [N] in 2010 than in 2009, depending on species (Table 4). A. canescens displayed 57\% less total shoot $\mathrm{N}$ content in 2010 than in 2009.

\section{Discussion}

Ongoing global climate change may affect ecosystem nutrient cycling, plant traits and community structure directly and indirectly. Because $\mathrm{N}$ is often a limiting nutrient and legumes play a significant role in $\mathrm{N}$ cycling, we examined the potential impacts of warming on (1) perennial prairie legume $\mathrm{N}_{2}$ fixation and three of its drivers (soil moisture, soil temperature and in situ net $\mathrm{N}$ mineralisation rates), and (2) legume biomass and tissue $\mathrm{N}$ chemistry using a manipulative field warming and biodiversity study with two levels of warming. We also examined the effect of species diversity on any response to warming. As expected, 
Table 3. F-ratios (degrees of freedom) from ANOVAs used to analyse variables measured on legume individuals during the first 2 years of a warming and plant diversity experiment

Y, year; S, species; D, diversity; $\mathrm{W}$, warming; $\dagger$, significant effect at $P<0.1{ }^{*}$, significant effect at $P<0.05$. The first degrees of freedom (d.f.) value is the numerator d.f. and the second value is the denominator d.f.

\begin{tabular}{|c|c|c|c|c|c|}
\hline Model and subset of data analysed ${ }^{\mathrm{A}}$ & Effect $^{\mathrm{B}}$ & $\begin{array}{l}\text { Aboveground } \\
\text { biomass }\end{array}$ & Shoot $[\mathrm{N}]$ & $\begin{array}{l}\% \mathrm{~N} \text { derived } \\
\text { from fixation }\end{array}$ & $\begin{array}{l}\text { Total shoot } \\
\text { N content }\end{array}$ \\
\hline $\begin{array}{l}\text { Model 1: Dalea purpurea } \\
\text { and Lespedeza capitata individuals } \\
\text { in 4- and 16-species plots }\end{array}$ & $\begin{array}{c}\mathrm{Y} \\
\mathrm{S} \\
\mathrm{D} \\
\mathrm{W} \\
\mathrm{Y} \times \mathrm{S} \\
\mathrm{Y} \times \mathrm{D} \\
\mathrm{Y} \times \mathrm{W} \\
\mathrm{S} \times \mathrm{D} \\
\mathrm{S} \times \mathrm{W} \\
\mathrm{D} \times \mathrm{W} \\
\mathrm{Y} \times \mathrm{D} \times \mathrm{W}\end{array}$ & $\begin{array}{c}2.0_{(1,70)} \\
39.8_{(1,99)}{ }^{*} \\
20.2_{(1,11)}{ }^{*} \\
5.0_{(2,25)}{ }^{*} \\
0.3_{(1,71)} \\
2.4_{(1,71)} \\
4.7_{(2,70)}{ }^{*} \\
102 \cdot 2_{(1,89)}{ }^{*} \\
3.0_{(2,88)}^{\dagger} \\
0.1_{(2,25)} \\
1.7_{(2,71)}\end{array}$ & $\begin{array}{c}51.3_{(1,171)} * \\
7.3_{(1,72)} * \\
0.2_{(1,13)} \\
8.4_{(2,27)} * \\
0.7_{(1,166)} \\
0.3_{(1,72)} \\
4.0_{(2,170)} * \\
3.5_{(1,72)}^{\dagger} \\
2.5_{(2,102)}^{\dagger} \\
0.1_{(2,27)} \\
3.5_{(2,170)} *\end{array}$ & $\begin{array}{c}59 \cdot 3_{(1,171)} * \\
39 \cdot 1_{(1,53)} * \\
10.2_{(1,13)} * \\
0.6_{(2,30)} \\
24.0_{(1,167)} * \\
12 \cdot 5_{(1,171)} * \\
0.7_{(2,170)} \\
0.2_{(1,54)} \\
4.6_{(2,98)} * \\
0.1_{(2,30)} \\
0.1_{(2,170)}\end{array}$ & $\begin{array}{c}0.7_{(1,54)} \\
0.2_{(1,38)} \\
44.7_{(1,13)} * \\
3.1_{(2,17)} \\
0.1_{(1,52)} \\
0.3_{(1,54)} \\
0.5_{(2,59)} \\
13.0_{(1,38)} * \\
0.2_{(2,60)} \\
0.4_{(2,59)} \\
0.4_{(2,59)}\end{array}$ \\
\hline $\begin{array}{l}\text { Model 2: Individuals in } 1-\text {, } \\
\text { 4- and } 16 \text {-species plots with species } \\
\text { added as a random factor }\end{array}$ & $\begin{array}{c}\mathrm{Y} \\
\mathrm{D} \\
\mathrm{W} \\
\mathrm{Y} \times \mathrm{D} \\
\mathrm{Y} \times \mathrm{W} \\
\mathrm{D} \times \mathrm{W}\end{array}$ & $\begin{array}{c}1.8_{(1,174)} \\
14.0_{(2,15)}{ }^{*} \\
5.5_{(2,132)}{ }^{*} \\
4.9_{(2,175)}{ }^{*} \\
2.9_{(2,175)} \\
3 \cdot 6_{(4,101)}{ }^{*}\end{array}$ & $\begin{array}{c}68.3_{(1,371)} * \\
12.2_{(2,15)} * \\
7.0_{(2,50)} * \\
1.0_{(2,372)} \\
4.4_{(2,368)} * \\
0.9_{(4,47)}\end{array}$ & $\begin{array}{c}13 \cdot 2_{(1,367)} \\
10.8_{(2,17)} \\
0.9_{(2,47)} \\
17 \cdot 7_{(2,368)} \\
1.2_{(2,367)} \\
1.3_{(4,44)}\end{array}$ & $\begin{array}{c}0.7_{(1,153)} \\
20.7_{(2,14)} \\
0.6_{(2,126)} \\
0.8_{(2,154)} \\
0.7_{(2,152)} \\
0.9_{(4,112)}\end{array}$ \\
\hline $\begin{array}{l}\text { Model 3: Individuals } \\
\text { in 16- and 32-species plots }\end{array}$ & $\begin{array}{c}\mathrm{Y} \\
\mathrm{S} \\
\mathrm{W} \\
\mathrm{Y} \times \mathrm{S} \\
\mathrm{Y} \times \mathrm{W} \\
\mathrm{S} \times \mathrm{W}\end{array}$ & $\begin{array}{c}29.0_{(1,211)}{ }^{*} \\
53 \cdot 8_{(3,227)} \\
3.4_{(2,24)} \\
8.3_{(3,211)} \\
1.1_{(2,211)} \\
2.6_{(6,232)}\end{array}$ & $\begin{array}{c}72.9_{(1,443)}{ }^{*} \\
61.2_{(3,414)}{ }^{*} \\
4.8_{(2,30)}{ }^{*} \\
2.9_{(3,434)}{ }^{*} \\
6.5_{(2,446)}{ }^{*} \\
1.1_{(6,450)}\end{array}$ & $\begin{array}{c}31.7_{(1,441)}{ }^{*} \\
55 \cdot 6_{(3,442)} \\
1.4_{(2,25)} \\
4.1_{(3,431)}{ }^{*} \\
1.7_{(2,444)} \\
0.4_{(6,446)}\end{array}$ & $\begin{array}{c}8.4_{(1,203)}{ }^{*} \\
19.9_{(3,206)} \\
0.4_{(2,27)} \\
2.8_{(3,194)} \\
0.5_{(2,204)} \\
1.4_{(6,210)}\end{array}$ \\
\hline
\end{tabular}

${ }^{\mathrm{A}}$ Due to the structure of the data collected, three separate ANOVAs were run, each using a subset of the data and a slightly different model of effects.

${ }^{\mathrm{B}}$ Insignificant $(P>0.1)$ three-way and four-way interactions are not shown.

warming increased soil temperature and decreased soil moisture, but this response was most evident for the higher warming treatment, and for many measurement periods soil moisture did not differ between ambient and low warming conditions. Contrary to our expectations, net $\mathrm{N}$ mineralisation rates did not differ among warming treatments or diversity levels, but showed strong inter-annual variation during the autumn sampling period. We acknowledge that our ability to quantify $\mathrm{N}_{\mathrm{dfa}}$ was limited in our experimental setting. Given this caveat, we did not find support for any effect of warming treatment on $\mathrm{N}_{2}$ fixation, but found evidence for an effect of diversity. Both high and low warming decreased shoot $[\mathrm{N}]$, but only high warming increased aboveground biomass for two species. This higher biomass did not lead to higher aboveground $\mathrm{N}$ pools in these legumes, though, because of the lower shoot [N]. Species diversity only affected the response of soil temperature and biomass to experimental warming. Overall, these results suggest small potential legume-mediated changes to $\mathrm{N}$ cycling under elevated temperatures for this prairie ecosystem, and that climate change may affect ecosystem $\mathrm{N}$ cycling more via effects on legume abundance and tissue $\mathrm{N}$ chemistry than effects on $\mathrm{N}_{2}$ fixation. Low warming treatment values were usually intermediate between ambient and high warming conditions, but occasionally would be more similar to ambient conditions or to warming, depending on the variable and year.

\section{Temperature effects}

Contrary to expectation, we found no evidence that $\mathrm{N}_{2}$ fixation (estimated as the proportion of nitrogen derived from fixation, $\%$ $\mathrm{N}_{\text {dfa }}$ ) was affected by the warming treatment. As with net $\mathrm{N}$ mineralisation, the warming-induced soil moisture decreases may have offset the increases in soil temperature. Also, our net $\mathrm{N}$ mineralisation results indicate no change in plant-available soil $\mathrm{N}$ under warming. The effects of warming on these three drivers of $\mathrm{N}_{2}$ fixation probably combined to produce no change in the reliance on fixation. Elevated temperature could also affect $\mathrm{N}_{2}$ fixation through its effect on nodulation (Purwantari et al. 1995; Lira Junior et al. 2005; Whittington et al. 2012). We found no effect of warming treatment on nodule fresh weight, which ranged from $0 \mathrm{~g} \mathrm{~m}^{-3}$ to $240 \mathrm{~g} \mathrm{~m}^{-3}$ among subplots in 2011 (data not shown). Warming affected $\mathrm{N}_{2}$ fixation in several other field warming studies (Lilley et al. 2001; Garten et al. 2008). The lack of any warming-induced changes to $\% \mathrm{~N}_{\text {dfa }}$ and total $\mathrm{N}$ content in our study suggests that the amount of fixed $\mathrm{N}$ added to these systems may not change due to future temperature increases of the magnitudes we imposed. However, temperature-dependent shifts in the abundance of various legume species could change $\mathrm{N}$ input rates.

The ${ }^{15} \mathrm{~N}$ natural abundance method for measuring $\% \mathrm{~N}_{\mathrm{dfa}}$ used in this study is not without limitations (Handley and Raven 1992; Boddey et al. 2000). Our values of $\% \mathrm{~N}_{\mathrm{dfa}}$ may be inflated, since 

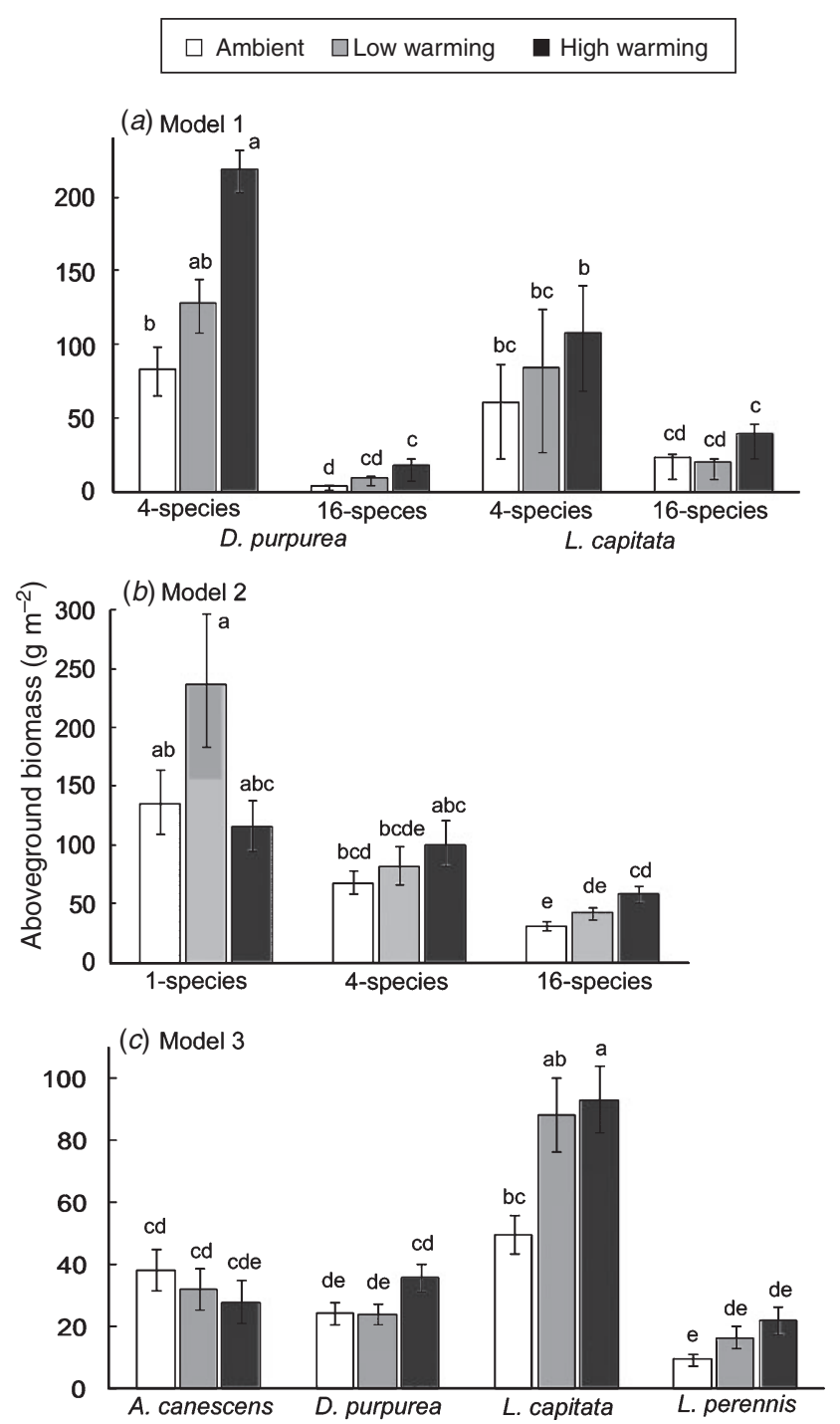

Fig. 3. The effect of warming on aboveground biomass as analysed with three different subsets of data. ( $a$ ) The effect of warming on Dalea purpurea and Lespedeza capitata biomass (Model 1). Only 2010 data are shown, as this was the only year to show a significant effect of warming. (b) The influence of diversity on the warming response of biomass (Model 2). Means are pooled across species and years. (c) The effect of warming on biomass for each species (Amorpha canescens, D. purpurea, L. captitata and Lupinus perennis) in diverse plots (Model 3). Means are pooled across 16- and 32-species plots for both years. Error bars represent \pm s.e. Letters indicate significant differences $(P<0.05$, post hoc Tukey's honestly significant difference (HSD) tests after ANOVA) among means within each model.

we assumed at least one individual of each species was relying solely on fixation each year. However, our values are still relatively low compared with values reported for the same species in a different field experiment in the same field (West et al. 2005). Our low values most probably occurred because several legume individuals exhibited higher $\delta^{15} \mathrm{~N}$ values than the mean reference values. Since a negative reliance on fixation is not feasible, we set the $\% \mathrm{~N}_{\mathrm{dfa}}$ value to zero for these individuals. Our data suggest that this method for measuring $\mathrm{N}_{2}$ fixation may
Table 4. Shoot $[\mathrm{N}]\left(\mathrm{mg} \mathrm{g}^{-1}\right)$ of four legumes (Amorpha canescens, Dalea purpurea, Lespedeza captitata and Lupinus perennis) grown at three diversity levels and under two warming treatments for 2 years

Values are means \pm s.e. Letters indicate significant differences among means within each effect $(P<0.05$, post hoc Tukey's honestly significant difference tests after ANOVA)

\begin{tabular}{lccc}
\hline Effect & Level & 2009 & 2010 \\
\hline Species $^{\mathrm{A}}$ & A. canescens $^{\text {Year }}$ & $14.4 \pm 0.3^{\mathrm{c}}$ & $17.5 \pm 0.4^{\mathrm{ab}}$ \\
& D. purpurea & $17.0 \pm 0.3^{\mathrm{ab}}$ & $18.9 \pm 0.4^{\mathrm{a}}$ \\
& L. capitata $^{\mathrm{a}}$ & $15.0 \pm 0.2^{\mathrm{bc}}$ & $17.5 \pm 0.3^{\mathrm{a}}$ \\
& L. perennis & $9.8 \pm 0.3^{\mathrm{d}}$ & $14.0 \pm 0.9^{\mathrm{c}}$ \\
\hline Warming treatment $^{*}$ & Ambient & $14.7 \pm 0.5^{\mathrm{cd}}$ & $20.0 \pm 0.7^{\mathrm{a}}$ \\
& Low & $14.3 \pm 0.4^{\mathrm{d}}$ & $17.4 \pm 0.5^{\mathrm{b}}$ \\
& High & $14.3 \pm 0.5^{\text {cd }}$ & $16.1 \pm 0.5^{\mathrm{bc}}$ \\
\hline Diversity $^{\mathrm{B}}$ & 1 species $^{\mathrm{a}}$ & $16.2 \pm 0.8$ & $21.0 \pm 1.0$ \\
& 4 species $^{\mathrm{b}}$ & $16.3 \pm 0.4$ & $18.4 \pm 0.4$ \\
& 16 species $^{\mathrm{b}}$ & $13.4 \pm 0.3$ & $16.9 \pm 0.5$
\end{tabular}

${ }^{\mathrm{A}}$ Values shown are means pooled across $16-$ and 32 -species plots.

${ }^{\mathrm{B}}$ There were no diversity $\times$ year interactions, so the differences between the diversity levels are shown with letters next to the level; values are means pooled across species and warming treatments.

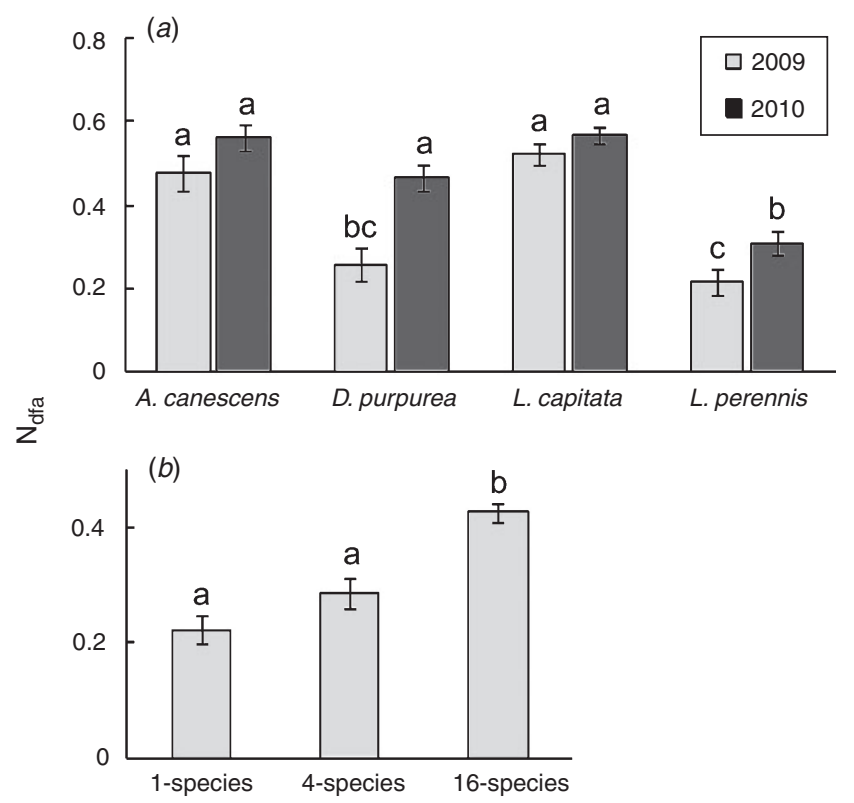

Fig. 4. The effect of year and diversity on the proportion of $\mathrm{N}$ derived from fixation $\left(\mathrm{N}_{\mathrm{dfa}}\right)$. (a) Interannual variation in $\mathrm{N}_{\mathrm{dfa}}$ for the four focal legumes (Amorpha canescens, Dalea purpurea, Lespedeza captitata and Lupinus perennis). (b) The effect of plant diversity on $\mathrm{N}_{\mathrm{dfa}}$. Error bars indicate \pm s.e. Letters indicate significant differences among means $(P<0.05$, post hoc Tukey's honestly significant difference (HSD) tests after ANOVA).

not be optimal for this system, since there was not a large difference in the $\delta^{15} \mathrm{~N}$ values of legumes and reference plants. Since we did not see a large difference between legume $\delta^{15} \mathrm{~N}$ values and reference plant $\delta^{15} \mathrm{~N}$ values, our $\% \mathrm{~N}_{\mathrm{dfa}}$ values should be interpreted with caution and should not be considered as quantitative measurements of $\mathrm{N}_{2}$ fixation, and it would be 
inappropriate to use these values to estimate amount of fixation on an ecosystem-wide basis (Ledgard and Peoples 1988). An alternative to using $\% \mathrm{~N}_{\mathrm{dfa}}$ values calculated with a mixing model is to simply examine the legume $\delta^{15} \mathrm{~N}$ values. Analysis of the $\delta^{15} \mathrm{~N}$ values yielded results (not shown) similar to those seen for $\% \mathrm{~N}_{\mathrm{dfa}}$ (i.e. diversity and year affected $\delta^{15} \mathrm{~N}$ values but warming did not), suggesting that the $\% \mathrm{~N}_{\text {dfa }}$ results are not false trends created by the calculations necessary for the mixing model.

Net $\mathrm{N}$ mineralisation is often used as an index of plantavailable N (Schimel and Bennett 2004). We found no effect of warming or diversity on net $\mathrm{N}$ mineralisation rates. Previous studies have yielded mixed results on the effect of warming on net $\mathrm{N}$ mineralisation (Rustad et al. 2001). In a subalpine warming experiment in the Rocky Mountains, warming did not affect $\mathrm{N}$ transformation rates in a mesic site, but did increase net $\mathrm{N}$ mineralisation in a dry site for 2 out of 3 years (Shaw and Harte 2001). Interannual variation in the warming response of $\mathrm{N}$ mineralisation was also seen in an Oklahoma tallgrass prairie warming experiment, with warming increasing it one year and decreasing it the next (Wan et al.2005). A lack of response may be due to the antagonistic effects of decreasing soil moisture and increasing soil temperature. We did find that the high and low warming treatments increased net ammonification in the very wet autumn of 2010, but warming had no effect on net nitrification. In 2010 , net nitrification was $\sim 15$ times larger than ammonification and probably had more influence on net $\mathrm{N}$ mineralisation rates. The increase in ammonification may have arisen due to higher gross mineralisation rates, lower microbial immobilisation or decreased nitrification rates under warming. Contrary to our findings, warming increased immobilisation during the first two years of two other field warming studies (Shaw and Harte 2001; Larsen et al. 2011).

D. purpurea and L. perennis both had significant aboveground biomass responses to warming treatments, with three and two times, respectively, higher biomass under warming on average across the four-, 16- and 32-species plots in 2010. The biomass harvest occurred when $L$. perennis was senescing. For this species, warming may have delayed senescence, leading to higher biomass in these subplots at the time of harvest, although we detected no effect of warming on the community normalised difference vegetation index during this time in 2011 (Whittington 2012). In a growth chamber experiment with seedlings of these species, L. capitata was the only species to display enhanced growth under elevated temperatures, although there was a trend for a small increase in biomass for D. purpurea (Whittington et al. 2012). These differences might mean that seedlings and mature plants respond differently to warming and these differences could interact to affect community structure over time. The differences between the two studies might also be due to indirect interactions that occur in field settings but not in the controlled environment of a growth chamber.

Warming decreased legume shoot $[\mathrm{N}]$ concentrations, with reductions of $8-32 \%$ depending on species, suggesting a decrease in mineral $\mathrm{N}$ uptake. A reduction in uptake could be due to decreased soil moisture or undetected decreases in soil $\mathrm{N}$ availability. We also cannot rule out the possibility of warming effects on root biomass or architecture that could also affect $\mathrm{N}$ uptake. Additionally, the increase in biomass production under warming observed for $D$. purpurea and $L$. perennis could account for the decrease in shoot [N], even if mineral $\mathrm{N}$ uptake remained unaffected for these two species. Previous studies have yielded mixed results on the impact of warming on tissue $\mathrm{N}$ concentrations. Warming decreased shoot $[\mathrm{N}]$ in several Oklahoma tallgrass prairie species including Ambrosia psilostachya DC., Aster ericoides L., Dichanthelium oligosanathes (Shult.) Gould, Schizachyrium scoparium (Michx.) Nash, and Sporobolus asper (Beauv.) Kunth (An et al. 2005). Similar results have been found for subterranean clover (Trifolium subterraneum L.) (Lilley et al. 2001) and rhizoma peanut (Arachis glabrata Benth.) (Fritschi et al. 1999), Warming, however, was found to increase [N] in a moist tundra ecosystem (Welker et al. 2005), and the authors attribute this increase to an increase in $\mathrm{N}$ mineralisation. In an oldfield grassland community in Tennessee, warming had no effect on shoot $[\mathrm{N}]$ in several species, including two legumes (Garten et al. 2008). Decreases in shoot [N] (and resulting increases in shoot $\mathrm{C}: \mathrm{N}$ ) may affect herbivory and litter chemistry, which, in turn, will affect decomposition (Hobbie 1992; Cornwell et al. 2008). Decreases in shoot $[N]$ may also decrease the stimulatory effect these legumes have on mineralisation and, in turn, decrease the stimulatory effect they can have on their nonlegume neighbours (Lee et al. 2003; Hille Ris Lambers et al. 2004). These effects may then feed back to affect nutrient cycling, plants and other trophic levels.

Despite the reduction in shoot $[\mathrm{N}]$ seen under warming in our experiment, total shoot $\mathrm{N}$ content was not affected by warming, indicating that total aboveground biomass $\mathrm{N}$ pools in legumes were unchanged. For D. purpurea and L. perennis, the decrease in $[\mathrm{N}]$ counteracted the effect of increased biomass under warming. If the reliance on $\mathrm{N}_{2}$ fixation remains constant, the lack of a warming effect on legume aboveground $\mathrm{N}$ pools suggests that the amount of fixed $\mathrm{N}$ added to this system by these legumes would remain unchanged in the future.

\section{Diversity effects}

We found support that nitrogen fixation varied among diversity levels. Legumes also had greater reliance on fixation as diversity increased, perhaps because of stronger competition for mineral $\mathrm{N}$ in the presence of many nonlegume neighbours, including grasses, than they experience in less diverse plots (Fargione and Tilman 2005). A decrease in competition for $\mathrm{N}$ in lower diversity plots was also visible in our [N] results. Shoot [N] increased with decreasing diversity for these legumes, with $22 \%$ higher $[\mathrm{N}]$ in monoculture plots than in plots with 16 species. Evidence for this phenomenon has also been found in several other studies (Carlsson et al. 2009; Roscher et al. 2011). These results suggest that any warming-induced changes in diversity or species composition may indirectly affect fixation rates and, in turn, the amount of fixed $\mathrm{N}$ that is added to the community.

\section{Warming and diversity interactions}

Our experimental design allowed us to examine the potential influence of plant species diversity on the effects of warming in these communities. Diversity did not affect the warming response in any variables except soil temperature and aboveground biomass. The increase in surface soil temperature under warming was stronger at lower diversity levels. This diversity 
effect may have been caused by decreased evapotranspiration at higher diversity because of greater shading of the soil surface and by increased interception of infrared radiation due to greater leaf biomass. The higher biomass in more diverse plots may cause higher transpiration rates and higher air humidity. The higher humidity in more diverse plots may have absorbed more of the infrared radiation, decreasing the amount that reached the soil surface.

The lack of strong diversity effects on the warming response suggests that species composition did not influence the response to warming. By contrast, a European grassland warming and diversity experiment (De Boeck et al. 2008) found that warminginduced decreases in aboveground biomass were higher at higher species diversity. The authors attribute this interaction to increased evapotranspiration and thus increased drought conditions under warming in more diverse communities compared with the drought experienced under warming in less diverse communities. However, their experiment was performed in mesocosms with plants that had been growing for only 3 years. These relatively young plants may not have had to time to develop large root systems, making them more vulnerable to the effects of warming on soil moisture. Our warming experiment investigated the effect of warming on established ( 15 -year-old) plants that were likely to have large root systems. The legumes in our study may have access to deep water and thus the warming-induced decreases in soil moisture did not inhibit biomass production.

\section{Interannual variability and seasonal effects}

Several variables, including $\% \mathrm{~N}_{\mathrm{dfa}}$, soil moisture, net mineralisation and shoot $[\mathrm{N}]$, displayed significant interannual variation. The differences between the years for many of these variables is most likely to be due to the precipitation differences between the years, suggesting that these variables may be affected more by future changes in precipitation rather than in temperature. Percent $\mathrm{N}_{\mathrm{dfa}}$ and shoot $[\mathrm{N}]$ were higher in the wetter and warmer 2010 than the drier 2009. Interannual variability in net $\mathrm{N}$ mineralisation was only seen during the autumn period, with much higher rates during the autumn of 2010 compared with any other period. The reason for this is unclear. Possibly, decomposition of senesced $L$. perennis occurred during this period and the higher soil moisture in 2010 allowed a large pulse of mineralised $\mathrm{N}$ to be released. For all incubation periods except autumn 2010, net $\mathrm{N}$ mineralisation values ranged from -0.2 to $0.3 \mathrm{ugN} \mathrm{g}^{-1}$ soil day ${ }^{-1}$, which is several orders of magnitude smaller than values measured in 2007 reported previously for these plots (Fornara et al. 2009) but more similar to the gross mineralisation rates measured in these plots in 2000 (Zak et al. 2003). The reason behind this discrepancy is unclear, but may be due to variation in methods or relatively high concentrations of $\mathrm{NO}_{3}{ }^{-}$and $\mathrm{NH}_{4}{ }^{+}$occasionally found in our blanks.

Our results show that the impacts of temperature increases on legumes and $\mathrm{N}$ cycling were mainly mediated through changes in legume abundance and tissue chemistry, rather than $\mathrm{N}_{2}$ fixation. Warming decreased shoot $[\mathrm{N}]$ for all four species and increased shoot biomass for two species. Responses were generally stronger under high than low warming, with low warming responses usually intermediate between high warming and ambient conditions. The interactions between diversity and warming were rarely significant, suggesting that diversity had little influence on the warming responses of $\mathrm{N}$ cycling processes in our study system. However, many of the variables we measured showed strong differences between a very dry year and the following wet year, which suggests that these processes are responsive to water availability. However, a longer experiment will be needed to test for the interactive effects of warming and year-to-year variation in precipitation.

\section{Acknowledgements}

Raw soil temperature and biomass data were organised and summarised by Peter Wragg and Margaret Kosmala, respectively. We thank Troy Mielke and all the Cedar Creek interns who assisted in data collection. Rebecca Montgomery and Sarah Hobbie provided useful comments on previous drafts. We also thank four anonymous reviewers for their insightful suggestions on previous drafts. Funding for this research was provided by a National Science Foundation Cedar Creek Long Term Ecological Research grant DEB-0620652 to DT, a Grant-in-Aid-of-Research from the University of Minnesota to JSP, a State of Minnesota Legislative and Citizens Committee on Minnesota Resources grant to DT and JSP, and a University of Minnesota College of Biological Sciences Plant Traits Course research grant to HRW.

\section{References}

Allison SD, Treseder KK (2008) Warming and drying suppress microbial activity and carbon cycling in boreal forest soils. Global Change Biology 14, 2898-2909. doi:10.1111/j.1365-2486.2008.01716.x

Allos HF, Bartholomew WV (1955) Effect of available nitrogen on symbiotic fixation. Soil Science Society of America Journal 19, 182-184. doi:10.2136/sssaj1955.03615995001900020018x

An YA, Wan SQ, Zhou XH, Subedar AA, Wallace LL, Luo YQ (2005) Plant nitrogen concentration, use efficiency, and contents in a tallgrass prairie ecosystem under experimental warming. Global Change Biology 11, 1733-1744. doi:10.1111/j.1365-2486.2005.01030.x

Aranjuelo I, Irigoyen JJ, Sanchez-Diaz M (2007) Effect of elevated temperature and water availability on $\mathrm{CO}_{2}$ exchange and nitrogen fixation of nodulated alfalfa plants. Environmental and Experimental Botany 59, 99-108. doi:10.1016/j.envexpbot.2005.10.008

Barrios S, Raggio N, Raggio M (1963) Effect of temperature on infection of isolated bean roots by rhizobia. Plant Physiology 38, 171-174. doi:10. 1104/pp.38.2.171

Boddey RM, Peoples MB, Palmer B, Dart PJ (2000) Use of the ${ }^{15} \mathrm{~N}$ natural abundance technique to quantify biological nitrogen fixation by woody perennials. Nutrient Cycling in Agroecosystems 57, 235-270. doi:10.10 23/A:1009890514844

Carlsson G, Palmborg C, Jumpponen A, Scherer-Lorenzen M, Hogberg P, Huss-Danell K (2009) $\mathrm{N}_{2}$ fixation in three perennial Trifolium species in experimental grasslands of varied plant species richness and composition. Plant Ecology 205, 87-104. doi:10.1007/s11258-009-9600-9

Cornwell WK, Cornelissen JHC, Amatangelo K, Dorrepaal E, Eviner VT, Godoy O, Hobbie SE, Hoorens B, Kurokawa H, Perez-Harguindeguy N, Quested HM, Santiago LS, Wardle DA, Wright IJ, Aerts R, Allison SD, van Bodegom P, Brovkin V, Chatain A, Callaghan TV, Diaz S, Garnier E, Gurvich DE, Kazakou E, Klein JA, Read J, Reich PB, Soudzilovskaia NA, Vaieretti MV, Westoby M (2008) Plant species traits are the predominant control on litter decomposition rates within biomes worldwide. Ecology Letters 11, 1065-1071. doi:10.1111/j.1461-0248.2008.01219.x

Cedar Creek Ecosystem Science Reserve (CCESR) (2009) Weather data. (CCESR, St Paul). Available online at www.cedarcreek.umn.edu/ research/weather [Verified 4 June 2013].

Craine JM, Jackson RD (2010) Plant nitrogen and phosphorus limitation in 98 North American grassland soils. Plant and Soil 334, 73-84. doi:10. 1007/s11104-009-0237-1 
Craine JM, Tilman D, Wedin D, Reich P, Tjoelker M, Knops J (2002) Functional traits, productivity and effects on nitrogen cycling of 33 grassland species. Functional Ecology 16, 563-574. doi:10.1046/j.13 65-2435.2002.00660.x

De Boeck HJ, Lemmens C, Bossuyt H, Malchair S, Carnol M, Merckx R, Nijs I, Ceulemans R (2006) How do climate warming and plant species richness affect water use in experimental grasslands? Plant and Soil 288, 249-261. doi:10.1007/s11104-006-9112-5

De Boeck HJ, Lemmens C, Zavalloni C, Gielen B, Malchair S, Carnol M, Merckx R, Van den Berge J, Ceulemans R, Nijs I (2008) Biomass production in experimental grasslands of different species richness during three years of climate warming. Biogeosciences 5, 585-594. doi:10.5194/bg-5-585-2008

Dijkstra FA, Wrage K, Hobbie SE, Reich PB (2006) Tree patches show greater $\mathrm{N}$ losses but maintain higher soil $\mathrm{N}$ availability than grassland patches in a frequently burned oak savanna. Ecosystems 9, 441-452. doi:10.1007/s10021-006-0004-6

Doane TA, Horwath WR (2003) Spectrophotometric determination of nitrate with a single reagent. Analytical Letters 36, 2713-2722. doi:10. 1081/AL-120024647

Fargione JE, Tilman D (2005) Diversity decreases invasion via both sampling and complementarity effects. Ecology Letters 8, 604-611. doi:10.1111/ j.1461-0248.2005.00753.x

Finzi AC, Austin AT, Cleland EE, Frey SD, Houlton BZ, Wallenstein MD (2011) Responses and feedbacks of coupled biogeochemical cycles to climate change: examples from terrestrial ecosystems. Frontiers in Ecology and the Environment 9, 61-67. doi:10.1890/100001

Fornara DA, Tilman D (2009) Ecological mechanisms associated with the positive diversity-productivity relationship in an N-limited grassland. Ecology 90, 408-418. doi:10.1890/08-0325.1

Fornara DA, Tilman D, Hobbie SE (2009) Linkages between plant functional composition, fine root processes and potential soil $\mathrm{N}$ mineralization rates. Journal of Ecology 97, 48-56. doi:10.1111/j.1365-2745.2008.01453.x

Fritschi FB, Boote KJ, Sollenberger LE, Allen LHJ (1999) Carbon dioxide and temperature effects on forage establishment: tissue composition and nutritive value. Global Change Biology 5, 743-753. doi:10.1046/j.13 65-2486.1999.00260.x

Garten CT, Classen AT, Norby RJ, Brice DJ, Weltzin JF, Souza L (2008) Role of $\mathrm{N}_{2}$-fixation in constructed old-field communities under different regimes of $\left[\mathrm{CO}_{2}\right]$, temperature, and water availability. Ecosystems 11, 125-137. doi:10.1007/s10021-007-9112-1

Handley LL, Raven JA (1992) The use of natural abundance of nitrogen isotopes in plant physiology and ecology. Plant, Cell \& Environment 15, 965-985. doi:10.1111/j.1365-3040.1992.tb01650.x

Harding SC, Sheehy JE (1980) Influence of shoot and root temperature on leaf growth, photosynthesis and nitrogen-fixation of lucerne. Annals of Botany 45, 229-233.

Harte J, Torn MS, Chang F-R, Feifarek B, Kinzig AP, Shaw R, Shen K (1995) Global warming and soil microclimate: results from a meadow-warming experiment. Ecological Applications 5, 132-150. doi:10.2307/1942058

Hille Ris Lambers J, Harpole WS, Tilman D, Knops J, Reich PB (2004) Mechanisms responsible for the positive diversity-productivity relationship in Minnesota grasslands. Ecology Letters 7, 661-668. doi:10. 1111/j.1461-0248.2004.00623.x

Hobbie SE (1992) Effects of plant species on nutrient cycling. Trends in Ecology \& Evolution 7, 336-339. doi:10.1016/0169-5347(92)90126-V

Hooper DU, Chapin FS, Ewel JJ, Hector A, Inchausti P, Lavorel S, Lawton JH, Lodge DM, Loreau M, Naeem S, Schmid B, Setala H, Symstad AJ, Vandermeer J, Wardle DA (2005) Effects of biodiversity on ecosystem functioning: A consensus of current knowledge. Ecological Monographs 75, 3-35. doi:10.1890/04-0922

Hungate BA, Dukes JS, Shaw MR, Luo YQ, Field CB (2003) Nitrogen and climate change. Science 302, 1512-1513. doi:10.1126/science.1091390
Hungria M, Franco AA (1993) Effects of high temperature on nodulation and nitrogen fixation by Phaseolus vulgaris L. Plant and Soil 149, 95-102. doi:10.1007/BF00010766

Kessler W, Boller BC, Nosberger J (1990) Distinct influence of root and shoot temperature on nitrogen fixation by white clover. Annals of Botany 65, 341-346.

Kindscher K, Tieszen LL (1998) Floristic and soil organic matter changes after five and thirty-five years of native tallgrass prairie restoration. Restoration Ecology 6, 181-196. doi:10.1111/j.1526-100X.1998.06210.x

Larsen KS, Andresen LC, Beier C, Jonasson S, Albert KR, Ambus P, Arndal MF, Carter MS, Christensen S, Holmstrup M, Ibrom A, Kongstad J, van der Linden L, Maraldo K, Michelsen A, Mikkelsen TN, Pilegaard K, Prieme A, Ro-Poulsen H, Schmidt IK, Selsted MB, Stevnbak K (2011) Reduced $\mathrm{N}$ cycling in response to elevated $\mathrm{CO}_{2}$, warming, and drought in a Danish heathland: synthesizing results of the CLIMAITE project after two years of treatments. Global Change Biology 17, 1884-1899. doi:10. $1111 / \mathrm{j} .1365-2486.2010 .02351 . \mathrm{x}$

LeBauer DS, Treseder KK (2008) Nitrogen limitation of net primary productivity in terrestrial ecosystems is globally distributed. Ecology 89, 371-379. doi:10.1890/06-2057.1

Ledgard SF, Peoples MB (1988) Measurement of nitrogen fixation in the field. In 'Advances in nitrogen cycling in agricultural ecosystems'. (Ed. JR Wilson) pp. 351-367. (CAB International: Wallingford, UK)

Lee TD, Reich PB, Tjoelker MG (2003) Legume presence increases photosynthesis and $\mathrm{N}$ concentrations of co-occurring non-fixers but does not modulate their responsiveness to carbon dioxide enrichment. Oecologia 137, 22-31. doi:10.1007/s00442-003-1309-1

Lilley JM, Bolger TP, Peoples MB, Gifford RM (2001) Nutritive value and the nitrogen dynamics of Trifolium subterraneum and Phalaris aquatica under warmer, high $\mathrm{CO}_{2}$ conditions. New Phytologist 150, 385-395. doi:10.1046/j.1469-8137.2001.00101.x

Lira Junior MA, Lima AST, Arruda JRF, Smith DL (2005) Effect of root temperature on nodule development of bean, lentil, and pea. Soil Biology \& Biochemistry 37, 235-239. doi:10.1016/j.soilbio.2004.07.032

Meyer DR, Anderson AJ (1959) Temperature and symbiotic nitrogen fixation. Nature 183, 61. doi:10.1038/183061a0

Oelmann Y, Buchmann N, Gleixner G, Habekost M, Roscher C, Rosenkranz S, Schulze ED, Steinbeiss S, Temperton VM, Weigelt A, Weisser WW, Wilcke W (2011) Plant diversity effects on aboveground and belowground $\mathrm{N}$ pools in temperate grassland ecosystems: development in the first 5 years after establishment. Global Biogeochemical Cycles 25, GB2014. doi:10.1029/2010GB003869

Piha MI, Munns DN (1987) Sensitivity of the common bean (Phaseolus vulgaris L.) symbiosis to high soil temperature. Plant and Soil $\mathbf{9 8 ,}$ 183-194. doi:10.1007/BF02374822

Piper JK, SchmidtES, Janzen AJ (2007) Effects of species richness on resident and target species components in a prairie restoration. Restoration Ecology 15, 189-198. doi:10.1111/j.1526-100X.2007.00203.x

Purwantari ND, Date RA, Dart PJ (1995) Nodulation and $\mathrm{N}_{2}$ fixation by Calliandra calothyrsus and Sesbania sesban grown at different root temperatures. Soil Biology \& Biochemistry 27, 421-425. doi:10.1016/ 0038-0717(95)98613-S

Roscher C, Thein S, Weigelt A, Temperton VM, Buchmann N, Schulze ED (2011) $\mathrm{N}_{2}$ fixation and performance of 12 legume species in a 6-year grassland biodiversity experiment. Plant and Soil 341, 333-348. doi:10. 1007/s11104-010-0647-0

Rustad LE, Campbell JL, Marion GM, Norby RJ, Mitchell MJ, Hartley AE, Cornelissen JHC, Gurevitch J (2001) A meta-analysis of the response of soil respiration, net nitrogen mineralization, and aboveground plant growth to experimental ecosystem warming. Oecologia 126, 543-562. doi: $10.1007 / \mathrm{s} 004420000544$

Schimel JP, Bennett J (2004) Nitrogen mineralization: challenges of a changing paradigm. Ecology 85, 591-602. doi:10.1890/03-8002 
Serraj R, Sinclair TR, Purcell LC (1999) Symbiotic $\mathrm{N}_{2}$ fixation response to drought. Journal of Experimental Botany 50, 143-155.

Shaver GR, Canadell J, Chapin FS, Gurevitch J, Harte J, Henry G, Ineson P, Jonasson S, Melillo J, Pitelka L, Rustad L (2000) Global warming and terrestrial ecosystems: a conceptual framework for analysis. Bioscience 50, 871-882. doi:10.1641/0006-3568(2000)050[0871:GWATEA]2.0. $\mathrm{CO} ; 2$

Shaw MR, Harte J (2001) Response of nitrogen cycling to simulated climate change: differential responses along a subalpine ecotone. Global Change Biology 7, 193-210. doi:10.1046/j.1365-2486.2001.00390.x

Shearer G, Kohl DH (1989) Estimates of $\mathrm{N}_{2}$ fixation in ecosystems: the need for and basis of the ${ }^{15} \mathrm{~N}$ natural abundance method. In 'Stable isotopes in ecological research'. (Eds PW Rundel, JR Ehleringer, KA Nagy) pp. 342-374. (Springer-Verlag: New York)

Sprent J (2001) 'Nodulation in legumes.' (Royal Botanic Gardens: Kew)

Thornton PE, Doney SC, Lindsay K, Moore JK, Mahowald N, Randerson JT, Fung I, Lamarque JF, Feddema JJ, Lee YH (2009) Carbon-nitrogen interactions regulate climate-carbon cycle feedbacks: results from an atmosphere-ocean general circulation model. Biogeosciences 6 , 2099-2120. doi:10.5194/bg-6-2099-2009

Tilman D, Reich PB, Knops J, Wedin D, Mielke T, Lehman C (2001) Diversity and productivity in a long-term grassland experiment. Science $\mathbf{2 9 4}$ 843-845. doi:10.1126/science.1060391

Verburg PSJ, Johnson DW, Schorran DE, Wallace LL, Luo Y, Arnone JA (2009) Impacts of an anomalously warm year on soil nitrogen availability in experimentally manipulated intact tallgrass prairie ecosystems. Global Change Biology 15, 888-900. doi:10.1111/j.1365-2486.2008.01797.x

Vitousek PM, Walker LR (1989) Biological invasion by Myrica faya in Hawai'i - plant demography, nitrogen fixation, ecosystem effects. Ecological Monographs 59, 247-265. doi:10.2307/1942601

Wan SQ, Hui DF, Wallace L, Luo YQ (2005) Direct and indirect effects of experimental warming on ecosystem carbon processes in a tallgrass prairie. Global Biogeochemical Cycles 19, GB2014. doi:10.1029/2004 GB002315
Weatherburn MW (1967) Phenol-hypochlorite reaction for determination of ammonia. Analytical Chemistry 39, 971-974. doi:10.1021/ac60252a045

Wedin DA, Tilman D (1990) Species effects on nitrogen cycling - a test with perennial grasses. Oecologia 84, 433-441.

Welker JM, Fahnestock JT, Sullivan PF, Chimner RA (2005) Leaf mineral nutrition of Arctic plants in response to warming and deeper snow in northern Alaska. Oikos 109, 167-177. doi:10.1111/j.0030-1299.2005. 13264.x

West JB, HilleRisLambers J, Lee TD, Hobbie SE, Reich PB (2005) Legume species identity and soil nitrogen supply determine symbiotic nitrogenfixation responses to elevated atmospheric $\left[\mathrm{CO}_{2}\right]$. New Phytologist 167, 523-530. doi:10.1111/j.1469-8137.2005.01444.x

Whittington HR (2012) 'Consequences of elevated temperature on prairie plants: legumes, nitrogen, and phenology.' (University of Minnesota: Minneapolis).

Whittington HR, Deede L, Powers JS (2012) Growth responses, biomass partitioning, and nitrogen isotopes of prairie legumes in response to elevated temperature and varying nitrogen source in a growth chamber experiment. American Journal of Botany 99, 838-846. doi:10.3732/ ajb. 1100283

Woodmansee RG, Vallis I, Mott JJ (1981) Grassland nitrogen. In 'Terrestrial nitrogen cycles'. (Eds FE Clark, T Rosswell) pp. 443-462. (Swedish National Science Research Council: Stockholm)

Zaehle S, Friedlingstein P, Friend AD (2010) Terrestrial nitrogen feedbacks may accelerate future climate change. Geophysical Research Letters 37 , L01401. doi:10.1029/2009GL041345

Zak DR, Holmes WE, White DC, Peacock AD, Tilman D (2003) Plant diversity, soil microbial communities, and ecosystem function: are there any links? Ecology 84, 2042-2050. doi:10.1890/02-0433

Zhou XH, Liu XZ, Wallace LL, Luo YQ (2007) Photosynthetic and respiratory acclimation to experimental warming for four species in a tallgrass prairie ecosystem. Journal of Integrative Plant Biology 49, 270-281. doi:10.1111/j.1744-7909.2007.00374.x 